ISSN: 2581-8341

Volume 03 Issue 12 December 2020

DOI: 10.47191/ijcsrr/V3-i12-10, Impact Factor: 6.595

IJCSRR@ 2020

www.ijcsrr.org

\title{
Principals Role in Inclusive Education: A Literature Review
}

\author{
Lilis Afrianti ${ }^{1}$, Ridwan Ridwan ${ }^{2}$, Hasan Hariri ${ }^{3}$, Riswanti Rini ${ }^{4}$, Sowiyah Sowiyah ${ }^{5}$ \\ ${ }^{1}$ SMPN 1 Gadingrejo, Pringsewu, Lampung, Indonesia \\ ${ }^{2}$ SMPN 3 Way Pengubuan, Lampung Tengah, Indonesia \\ ${ }^{3,45}$ Faculty of Teacher Training and Education, Unversitas Lampung, Indonesia
}

\begin{abstract}
The research objective of this article is to determine (1) what leadership style does the principal apply? (2) What strategy did the principal use? (3) What affects the leadership style and strategy of the principal in carrying out inclusive education? Using the search and review method of articles, the review process begins with the search engine, Google scholar and DOAJ, to search for articles with keywords. The results of the review show that (1) principals adopt different leadership styles and (2) principals implement various strategies. (3) The factors that influence the various styles and strategies are diverse resources, government policies, and local values.
\end{abstract}

KEYWORDS: education inclusive in the world, principalship

\section{INTRODUCTION}

In line with changes in the orientation of education delivery, at the global level there is a growing need for equal educational opportunities for all human beings, regardless of physical abilities (normal or disabled), social strata, gender, and ethnic, cultural and religious backgrounds. This global demand has given birth to a world declaration known as Education for All (UNESCO, 1990). The declaration raised awareness of 'Inclusive Education' as explicitly stated in the Salamanca Statement and Framework for Action, a product of the World Conference on Special Needs Education (Unesco, 1994b)

The World Conference and Special Needs Education: Access and Equality, June 1994 in Salamanca, Spain which states: “ that all nations must include education for children with special needs into their education policies to become the basis for implementing inclusive education for children with special needs.

So far, children with special needs have not received service and attention proportionally and professionally by public schools. According to Law No. 20 of 2003 Article 1 paragraph 1 Inclusive Education is a form of education that unites children with special needs with normal children in general for learning. The term inclusion is used to describe a program model that places students with disabilities and special conditions in regular classes, by providing support facilities, at the level of reach that is most likely (Armstrong, ,2006).

Based on the concept and definition of inclusion made several prepositions which he believed to be an inclusive paradigm, namely: 1) All students can learn, 2) All students are part of the school community, 3) All teachers can teach at all levels of students, 4) Teachers are responsible for teaching, and 5) The principal believes that they are responsible for educating all children in an effort to build the education system (Armstrong, ,2006). Inclusive leadership is not a term that indicates the position of a person or individual who carries out a predetermined task but as a collective process that exists in each person or who represents them (Ryan, 2006a). Then in his writing that inclusive leadership in inclusive education consists of several activities, which include supporting the implementation of inclusion, participating in education, building with full awareness, developing dialogue, prioritizing learning by doing, supporting inclusiveness as a decision-making strategy and policy, and building togetherness (Ryan, , 2006a).

In accordance with the results of research on leadership transformation in inclusive education which is mostly carried out in developed countries, such as research conducted by (Ryan, 2006 ) to reveal problems that occur in developing countries, especially in Indonesia, is very rarely carried out by researchers. . The main factor influencing student participation in developing inclusive education is culture or what can be called norms, values and ways of acceptance in implementing inclusive practices. The main focus for implementing sustainable inclusive education is leadership and is a commitment to implementing the principle of inclusion in education, both in the position and in the function of a leader. Developing an inclusive approach does not arise from the pupil as a mechanical process, or from the organization, at a certain level of participation, but rather an encouragement to develop an inclusive culture and as a commitment from all officials to carry out the process of increasing participation among teachers, parents and students 


\section{International Journal of Current Science Research and Review}

ISSN: 2581-8341

Volume 03 Issue 12 December 2020

DOI: 10.47191/ijcsrr/V3-i12-10, Impact Factor: 6.595

IJCSRR@ 2020

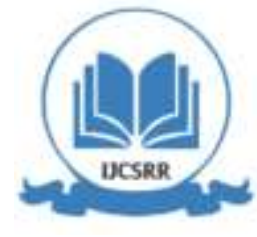

Www.ijcsrr.org

(Kugelmass, 2003). Thus the application of inclusive leadership in schools has greater potential compared to other public institutions, as stated by (Ryan, , 2006a) that one of the values contained in inclusive leadership is the value of democracy. That is, inclusive schools are willing to accept children with special needs to get educators in these public schools, giving them the same right to learn without differentiating from other students. Schools should also have adequate facilities for the education of children with special needs, including the presence of special education teachers at these schools.

Reasonable collaboration on an inclusive school culture has clear implications for basic leadership and decision making. The strength of school leadership is a commitment to inclusive values and essential to collaborative development and support. The position of the leader is to build collaborative practice in their interactions with staff, both formal and informal. The importance of the collaborative process is to distribute leadership to participate in decision making. The realization of the goals of inclusive education is very dependent on the skills and leadership policies of the principal who is one of the education leaders because the principal is a professional official in the school organization. Based on the description above, this article aims to find out more about answering the questions:

1. What leadership styles do the principals adopt?

2. What strategies do the principals use?

3. What influences the leadership style and strategy of the principal in implementing inclusive education?

\section{LITERATURE REVIEW AND HYPOTHESIS DEVELOPMENT}

\subsection{Principal Leadership}

Leadership is the ability to influence a group towards the achievement of goals (Robbins, , 2002). Gibson et al (, 1997) states that apart from leadership as influence, leadership is also an agent of change capable of influencing the behavior and performance of followers to achieve goals. To influence follower behavior and performance, this is where mobilization efforts are needed because each follower has different desires and expectations which lead to different behavior and performance, in line with this, the notion of leadership is the art of mobilizing other people as an effort to achieve common desires (Kouzes \& Posner, 2006)

From several definitions of leadership, there are several variations that differ from one another. However, the essence of this definition is a consistent ability (ability) to influence people, motivate to achieve common goals, and carry out functions that are important to achieve group success (Rosenbloom, , 2014). Leadership is different from management. Leadership is doing the right thing, whereas management is doing the right thing (leadership is doing something right, on the other hand management is doing something right (Bennis, Nanus, \& Purba, , 1990).

Finally, from all these definitions there are two important parts: What are the qualities of leadership and how to carry out leadership. There are a number of traits, qualities and skills of an effective leader, namely: 1) Believing in everything that can make success, 2) Having the skills and ability to communicate, 3) Psychologically being able to feel what other people feel or the ability to understand what followers want, 4) Having a strong energy to work or also known as a workaholic, 5) Able to provide careful assessment and consideration, 6) Have a firm stand, and 7) Able to empower subordinates to help carry out leadership tasks (Bennis \& Townsend, 1998).

Educational leadership involves an area that includes skills for managing processes such as curriculum, teaching-learning methods, classroom management, tutoring services, teacher monitoring and evaluation, educational settings, extra-curricular activities, and special education related to education and teaching. The knowledge base, the first field of proficiency for, school administration, promotes a theoretical basis for educational leadership. However, a fundamental difference between school administration and other administrations is expressed as educational leadership is defined as a separate ability of fields including skills to apply theoretical knowledge in schools (Marzano, Waters, \& McNulty, 2001).

The principal is the person who has the highest power in the school because the principal is responsible for all school activities and plays an important role in improving the quality of education and plays an important role in supporting the academic and social success of all students, especially students who have traditionally been marginalized because of race, ethnicity, language, ability, socioeconomic status, gender, and religion (Brooks \& Brooks, 2019). Principals play a key role in this domain by shaping the school environment, motivating and supporting continuous learning in school staff (Li, Hallinger, \& Ko, 2016).

The role of the principal is very important in transforming the educational process, student performance and learning outcomes because the quality of school leaders is related to student academic success; therefore, schools should invest in leadership training 


\section{International Journal of Current Science Research and Review}

ISSN: 2581-8341

Volume 03 Issue 12 December 2020

DOI: 10.47191/ijcsrr/V3-i12-10, Impact Factor: 6.595

IJCSRR@ 2020

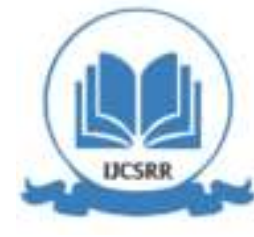

Www.ijcsrr.org

and development of school principals (Jones et al., 2015; Tingle, Corrales, \& Peters, 2019). Principal leadership is very important for the success of school organizations because leaders create positive change in education by encouraging school staff to take initiative and change (Quin, Deris, Bischoff, \& Johnson, , 2015). School leadership has a significant effect on the features of the school organ, which positively affects the quality of teaching and learning. The function of leadership is to build organizational conditions that foster high quality teaching and produce improvements in learning outcomes (Leithwood, Harris, \& Hopkins, , 2020).

\subsection{Inclusive Education}

Inclusive education is a process that focuses on and responds to the diverse needs of all learners through participation in learning, culture and community, and reduces exclusion in and from education (UNESCO, 2003). Inclusive education accommodates all learners regardless of their physical, intellectual, social, emotional, linguistic conditions and other conditions. This means including children with disabilities and talents, street and working children, children from remote and nomadic (nomadic) populations, children from linguistic, ethnic or cultural minorities, and children from other marginalized groups or areas.

Regular schools with an inclusive orientation are a very effective means of eradicating discrimination, creating warm societies, building an inclusive society, and making education successful for all (UNESCO, 1994a, 2003). Inclusive education aims to enable teachers and students to feel comfortable in diversity, and see diversity not as a problem, but as a challenge and enrichment for the learning environment (UNESCO, 2003). The basic principle of inclusion is to respect differences in human society. Through inclusion we seek and nurture the gift that is in everyone. In this way it can be believed that students in inclusive schools will be freed from tyranny by getting their rights (Kunc, 1992). Inclusive education is the integration of children with disabilities (with disabilities) into school programs (Smith, 2009).

Inclusive education is 'an increasingly contentious term that challenges educators and the education system' (Maclean, 2017). According to Law No. 20 of 2003, what is meant by children with special needs are children who have physical, emotional, mental, intellectual and / or social disabilities so that they are entitled to special education. In addition, children in remote or underdeveloped areas as well as remote indigenous communities have the right to receive special service education. And children who have the potential for intelligence and special talents are entitled to special education (Indonesia, 2003).

In line with this understanding, (Iswari, 2007) argues that children with special needs are children who experience physical, mental, emotional and social disabilities or a combination of these things in such a way that they are either permanent or temporary in nature so that they need educational services. From some of the opinions above, inclusion can mean the acceptance of children who have obstacles into the curriculum, environment, social interaction and self-concept (vision-mission) of the school. Inclusion means different things for each person. It is hoped that children with disabilities or special needs can be educated together with other normal children through this inclusive education, so that there is no gap between children with special needs and other normal children. In addition, children with special needs are also expected to maximize their potential.

Thus inclusive education is a special education service system that requires all children with special needs to be served in the closest school in the normal class together with their peers. For this reason, there is a need for good principal leadership that is able to facilitate the need for inclusion into the school system, as well as the need for collaboration with all parties involved in implementing inclusion in schools so that schools can become institutions that support meeting the special needs of each child. In addition, inclusive education is also expected to involve parents and the community in various educational activities.

\section{RESEARCH METHODOLOGY}

\subsection{Search and Review Methods}

The focus of this literature review is "Principal Leadership and Inclusive Education." The process of reviewing this literature begins with a search engine, Google scholar, to search for articles with the keywords "Leadership, Principal, inclusive. The criteria included in this study are as follows: The qualitative results of the principal's leadership in the implementation of Inclusive Education, Research conducted in the world, this study uses English. The number of related articles was taken from literature searches; there were 7310 articles from Google scholars, 32 articles related to leadership of the principle in the world and 302 articles related to inclusive education in the world from searching the Directory of Open Access Journals (DOAJ). A total of 60 articles were reviewed by researchers with similarities about leadership, school principal, and inclusive education. From the articles reviewed, 15 articles were selected as in the literature review process flow chart shown in Figure 1. 


\section{International Journal of Current Science Research and Review}

ISSN: 2581-8341

Volume 03 Issue 12 December 2020

DOI: 10.47191/ijcsrr/V3-i12-10, Impact Factor: 6.595

IJCSRR@ 2020

www.ijcsrr.org

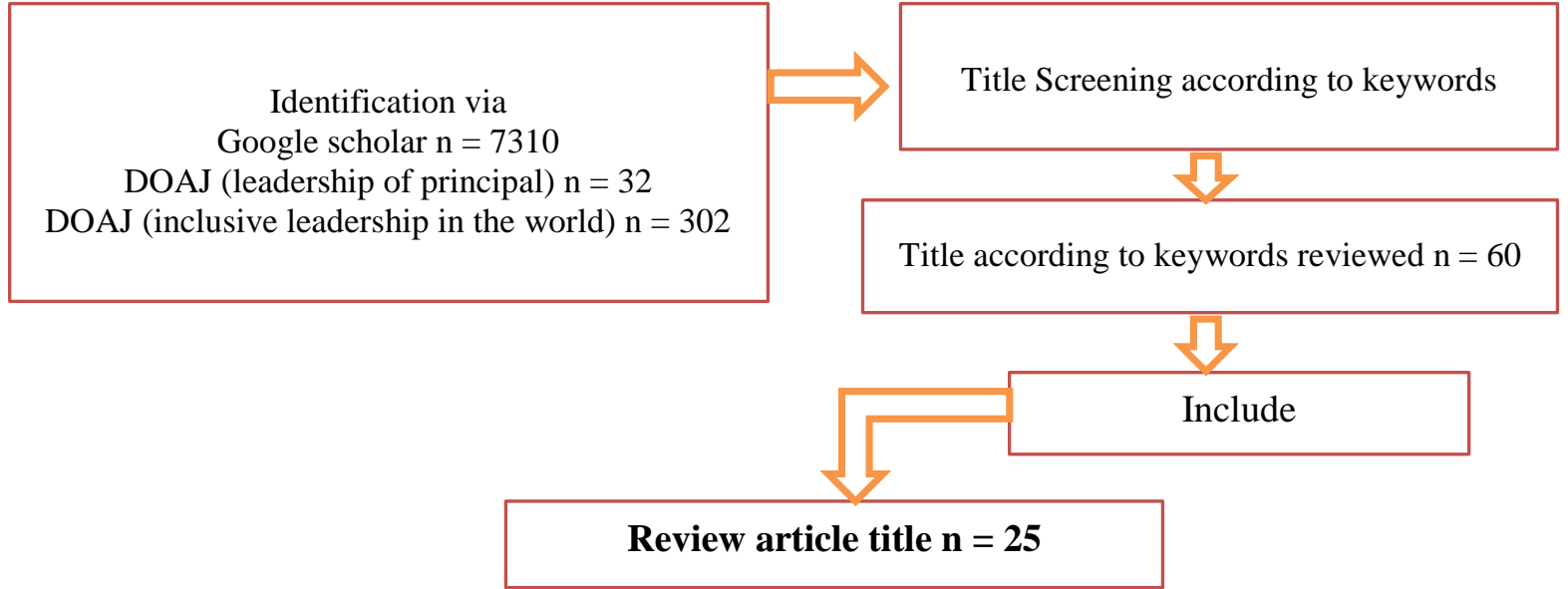

Figure 1. Flow of study selection systematic literature review

The following are the twenty-five journal articles reviewed as in table 1.

Table 1: Leadership of the Principal in the Implementation of Inclusive Education

\begin{tabular}{|c|c|c|c|c|c|}
\hline $\begin{array}{l}\text { Author } \\
\text { and Year }\end{array}$ & Title & Country & Method & Sample & Research result \\
\hline $\begin{array}{l}\text { Cam } \\
\text { Cobba, } \\
(2015)\end{array}$ & $\begin{array}{l}\text { Principals play many parts: a } \\
\text { review of the research on } \\
\text { school principals as special } \\
\text { education leaders 2001- } \\
2011\end{array}$ & Canada & Qualitative & $\begin{array}{l}187 \text { articles, a } \\
\text { collection of } \\
19 \text { studies } \\
\text { established }\end{array}$ & $\begin{array}{l}\text { Principals take on seven key roles } \\
\text { as they work as special education } \\
\text { leaders: visionary, partner, trainer, } \\
\text { conflict resolver, advocate, } \\
\text { interpreter, and organizer (Cobb, } \\
\text { 2015) }\end{array}$ \\
\hline
\end{tabular}

\begin{tabular}{|c|c|c|c|c|c|}
\hline $\begin{array}{l}\text { Suzanne } \\
\text { Carringto } \\
\text { n, Donna } \\
\text { Tangen \& } \\
\text { Denise } \\
\text { Beutel } \\
(2019)\end{array}$ & $\begin{array}{l}\text { Inclusive education in the } \\
\text { Asia Indo-Pacific region }\end{array}$ & $\begin{array}{l}\text { Asia Indo- } \\
\text { Pacific: } \\
\text { Banglades, } \\
\text { Sri Lanka, } \\
\text { Bhutan, } \\
\text { Kiribati, } \\
\text { Pacific } \\
\text { Islands and } \\
\text { Macau }\end{array}$ & $\begin{array}{l}\text { Review of } \\
\text { research } \\
\text { papers }\end{array}$ & $\begin{array}{l}7 \text { research } \\
\text { papers }\end{array}$ & $\begin{array}{l}\text { Illustrates how various } \\
\text { relationships and shared mitigation } \\
\text { between individuals and } \\
\text { communities can support work in } \\
\text { individual countries in promoting } \\
\text { and sustaining inclusive education } \\
\text { (Carrington, Tangen, \& Beutel, } \\
\text { 2019) }\end{array}$ \\
\hline $\begin{array}{l}\text { Markku } \\
\text { Jahnukain } \\
\text { en (2015) }\end{array}$ & $\begin{array}{l}\text { Inclusion, integration, or } \\
\text { what? A comparative study } \\
\text { of the school principals' } \\
\text { perceptions of inclusive and } \\
\text { special education in Finland } \\
\text { and in Alberta, Canada } \\
\text { Finland and in Alberta, } \\
\text { Canada }\end{array}$ & $\begin{array}{l}\text { Finland and } \\
\text { in Alberta, } \\
\text { Canada }\end{array}$ & $\begin{array}{l}\text { Objectives, } \\
\text { procedures, } \\
\text { interviews, } \\
\text { comparative } \\
\text { study }\end{array}$ & $\begin{array}{l}6 \text { schools in } \\
\text { Alberta } \\
\text { Canada, } 6 \\
\text { schools in } \\
\text { Finland }\end{array}$ & $\begin{array}{l}\text { It is evident that the true meaning of } \\
\text { 'inclusion' is always related to the } \\
\text { study of participants' own } \\
\text { understanding and significant } \\
\text { changes in the student population } \\
\text { with special needs, students who } \\
\text { currently come from various } \\
\text { foundation backgrounds with a } \\
\text { wide spectrum of new types of } \\
\text { special needs (Jahnukainen, 2015) }\end{array}$ \\
\hline
\end{tabular}




\section{International Journal of Current Science Research and Review}

ISSN: 2581-8341

Volume 03 Issue 12 December 2020

DOI: 10.47191/ijcsrr/V3-i12-10, Impact Factor: 6.595

IJCSRR@ 2020

www.ijcsrr.org

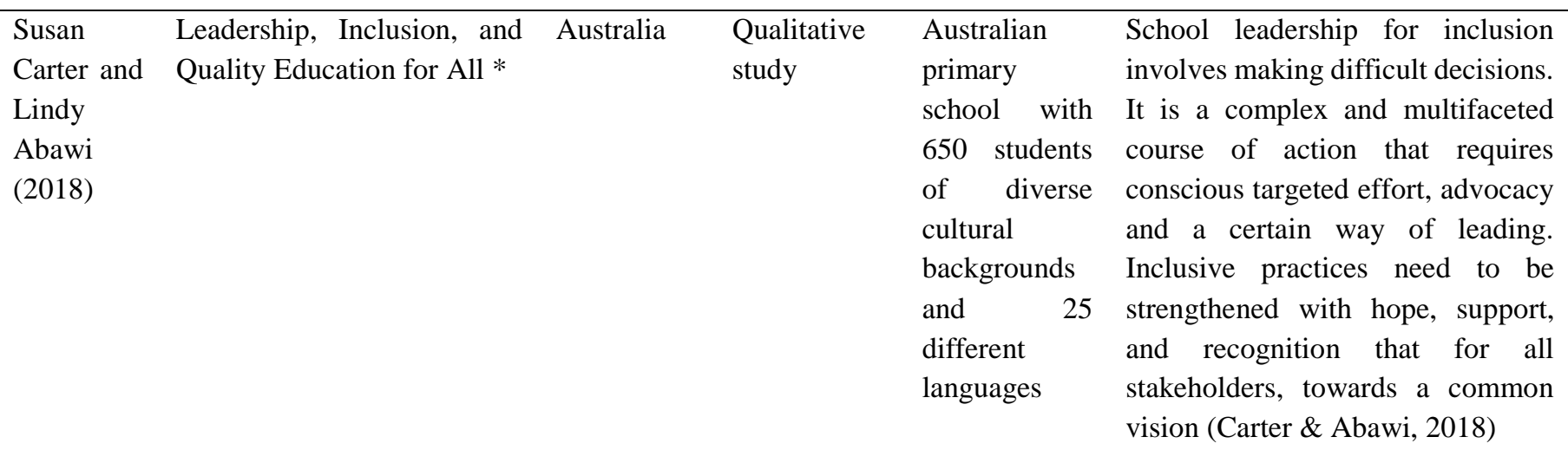

\begin{tabular}{|c|c|c|c|c|c|}
\hline $\begin{array}{l}\text { Michelle } \\
\text { Jones, } \\
\text { Donnie } \\
\text { Adams, } \\
\text { Mabel Tan } \\
\text { Hwee Joo, } \\
\text { Vasu } \\
\text { Muniandy } \\
\text { Corinne } \\
\text { Jacqueline } \\
\text { Perera \& } \\
\text { Alma } \\
\text { Harris } \\
\text { (2015) }\end{array}$ & $\begin{array}{l}\text { Contemporary challenges } \\
\text { and changes: principals' } \\
\text { leadership practices in } \\
\text { Malaysia }\end{array}$ & Malaysia & Quantitative & & $\begin{array}{l}\text { Principals in Malaysia increasingly } \\
\text { view their leadership practices as } \\
\text { transformational and distributed } \\
\text { (Jones et al., 2015) }\end{array}$ \\
\hline $\begin{array}{l}\text { David de } \\
\text { Matthews } \\
(2015)\end{array}$ & $\begin{array}{l}\text { Making Sense of Social } \\
\text { Justice Leadership: A Case } \\
\text { Study of a Principal's } \\
\text { Experiences to Create a } \\
\text { More Inclusive School }\end{array}$ & Texas & $\begin{array}{l}\text { Qualitative } \\
\text { case study } \\
\text { method }\end{array}$ & $\begin{array}{l}\text { Robinson } \\
\text { Elementary } \\
\text { School (ES), } \\
\text { with about } \\
450 \text { students }\end{array}$ & $\begin{array}{l}\text { Principals in this study are well- } \\
\text { oriented towards social justice, but } \\
\text { lack some of the skills and } \\
\text { experience needed to drive } \\
\text { sustainable change (DeMatthews, } \\
\text { 2015). }\end{array}$ \\
\hline $\begin{array}{l}\text { Brigitte } \\
\text { smit, } \\
\text { Vanessa } \\
\text { Scherman } \\
(2016)\end{array}$ & $\begin{array}{l}\text { A case for relational } \\
\text { leadership and an ethics of } \\
\text { care for counteracting } \\
\text { bullying at schools }\end{array}$ & $\begin{array}{l}\text { South } \\
\text { Africa }\end{array}$ & $\begin{array}{l}\text { Qualitative } \\
\text { ethnographi } \\
\text { c case study. }\end{array}$ & & $\begin{array}{l}\text { This theoretical exposition does not } \\
\text { draw empirical data, but rather } \\
\text { exposes the concepts of relational } \\
\text { leadership and care ethics to the } \\
\text { complementary leadership } \\
\text { approaches proposed in combating } \\
\text { and reducing school oppression. } \\
\text { This discussion is expected to add } \\
\text { to the atmosphere for further } \\
\text { empirical questions (Smit \& } \\
\text { Scherman, 2016) }\end{array}$ \\
\hline
\end{tabular}




\section{International Journal of Current Science Research and Review}

ISSN: 2581-8341

Volume 03 Issue 12 December 2020

DOI: 10.47191/ijcsrr/V3-i12-10, Impact Factor: 6.595

IJCSRR@ 2020

www.ijcsrr.org

\begin{tabular}{|c|c|c|c|}
\hline $\begin{array}{l}\text { Peder } \\
\text { Haur }\end{array}$ & Understanding inclusive & Norway & Qualitative \\
\hline
\end{tabular}

(2017)

\begin{tabular}{llll}
\hline Thang & Confucian $\quad$ Values and Vietnam & Qualitative 3 schools & The results of the study discuss \\
Dinh & School Leadership in & & school leadership which imitates \\
Truong, & Vietnam: Exploring the & the values of an 'indigenous \\
Philip & Influence of Culture on & perspective' (Truong, Hallinger, \& \\
Hallinger & Principal Decision Making & Sanga, 2017).
\end{tabular}

and

Kabini

Sanga

(2017)

\begin{tabular}{|c|c|c|c|c|c|}
\hline $\begin{array}{l}\text { Melanie } \\
\text { C. Brooks } \\
\text { \& Jeffrey } \\
\text { S. Brooks } \\
\text { (2019) }\end{array}$ & $\begin{array}{l}\text { Culturally (ir) relevant } \\
\text { school leadership: } \\
\text { Ethnoreligious conflict and } \\
\text { school administration in the } \\
\text { Philippines }\end{array}$ & Philippines & Qualitative & 42 Principals & $\begin{array}{l}\text { Some students receive the } \\
\text { opportunity to get a quality } \\
\text { education while others do not, } \\
\text { because the principal in Northern } \\
\text { Mindanao is a leader who } \\
\text { perpetuates the status quo of } \\
\text { marginalization of students from } \\
\text { various backgrounds (Brooks \& } \\
\text { Brooks, 2019). }\end{array}$ \\
\hline
\end{tabular}

\begin{tabular}{llllll}
\hline Ibrahim & Professional standards for & Turkey & The & A total of 483 & Determining required professional
\end{tabular}

Karatas school principals in Turkey

(2016)

\section{sequential participants}

exploration filled out the

method is a scale;

combination however, 155

of

qualitative

and

quantitative methods of them were

filled in

incorrectly, so

only 328 were

subjected to

statistical

analysis.
This article has discussed the understanding and practice of inclusive education, and the main challenges of developing inclusive education. It only deals with issues of broader relevance revealed in the research literature. The content has included elements related to the definition of inclusive education in relation to both the horizontal and vertical dimensions, the practice of inclusive education, the benefits of inclusive education and the competence of teachers for inclusive education (Haug, 2017). Determining required professional standards: School administration requires a total of 98 professional competencies under 8 areas of proficiency. According to the research results, the areas of the ability of school administrators are defined, respectively, as: (1) knowledge base (16 competencies), (2) organizational management (18 competencies), (3) effective communication (11 competencies), (4) technology leadership (13 competencies), (5) change 
ISSN: 2581-8341

Volume 03 Issue 12 December 2020

DOI: 10.47191/ijesrr/V3-i12-10, Impact Factor: 6.595

IJCSRR@ 2020

www.ijcsrr.org

leadership (12) competencies), (6)

educational leadership (11

competencies), (7) school-

community relations (10

competencies), and (8) society and

life (7 competencies) . (Karatas,

2016)

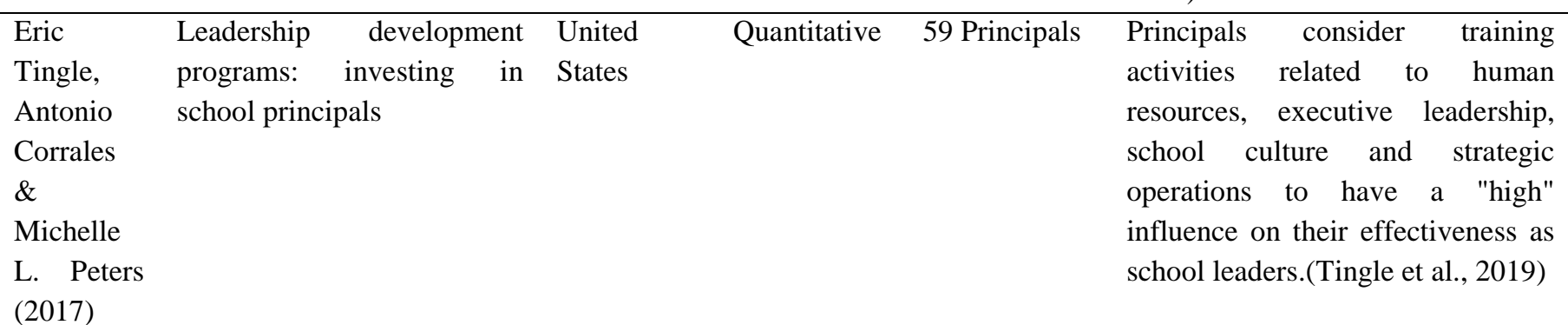

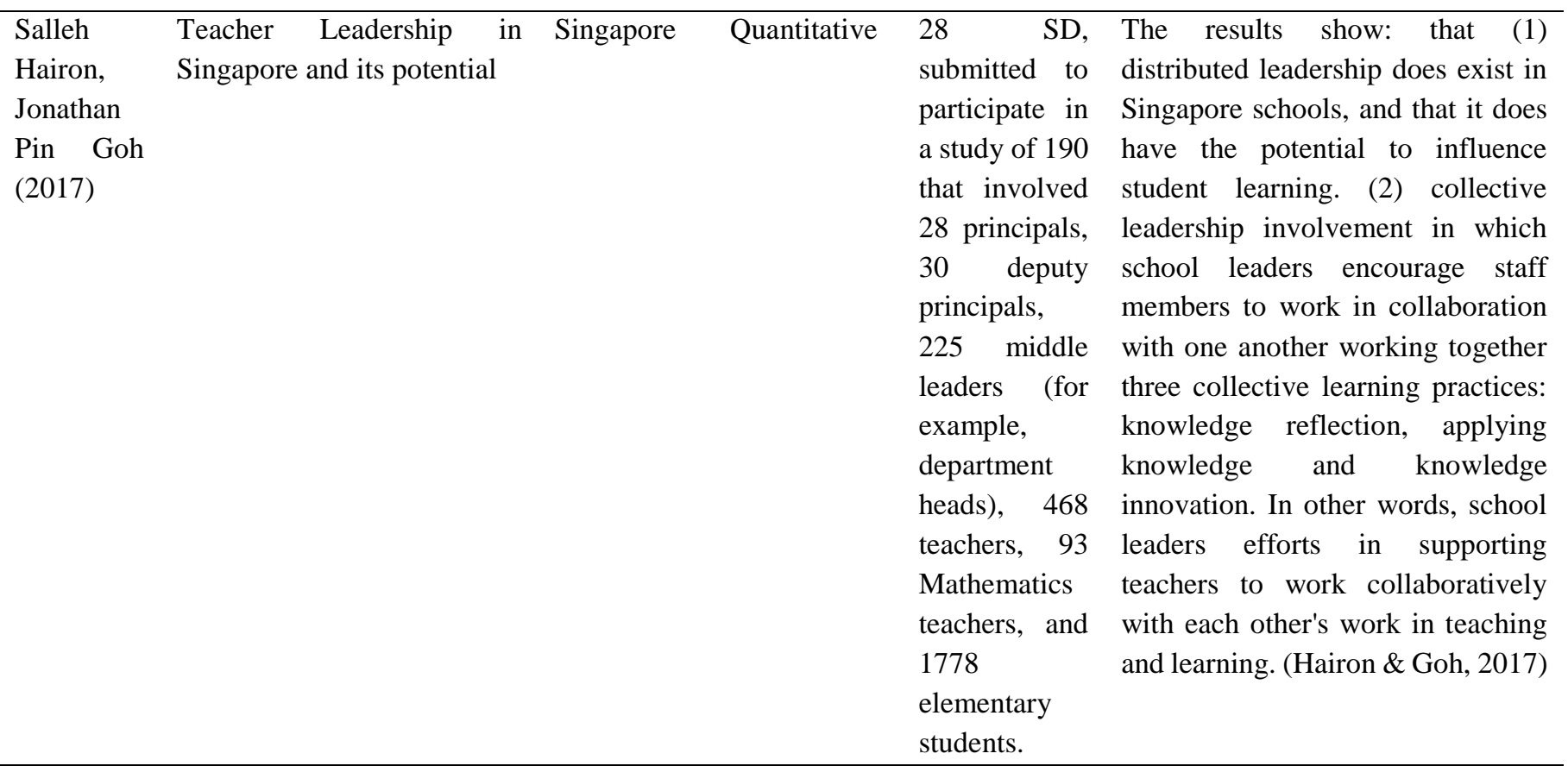

\begin{tabular}{|c|c|c|c|c|c|}
\hline $\begin{array}{l}\text { Eve } \\
\text { Eisensch } \\
\text { mid, Elina } \\
\text { Kuusisto, } \\
\text { Katrin } \\
\text { Poom- } \\
\text { Valickis \& } \\
\text { Kirsi Tirri } \\
\text { (2019) }\end{array}$ & $\begin{array}{l}\text { Virtues that create purpose } \\
\text { for ethical leadership: } \\
\text { Exemplary principals from } \\
\text { Estonia and Finland }\end{array}$ & Australia & Qualitative & - & $\begin{array}{l}\text { Principals demonstrate the virtue of } \\
\text { wisdom and knowledge in creating } \\
\text { long-term provisions for their } \\
\text { schools and building schools for } \\
\text { future generations. (Eisenschmidt, } \\
\text { Kuusisto, Poom-Valickis, \& Tirri, } \\
\text { 2019) }\end{array}$ \\
\hline $\begin{array}{l}\text { Angela } \\
\text { Urick, } \\
(2015)\end{array}$ & $\begin{array}{lcc}\text { Examining } & \text { US } & \text { Principal } \\
\text { perception } & \text { Of } & \text { Multiple } \\
\text { Leadership } & \text { styles } & \text { Used To }\end{array}$ & $\begin{array}{l}\text { United } \\
\text { States of } \\
\text { America }\end{array}$ & Quantitative & $\begin{array}{l}8,524 \text { school } \\
\text { principals }\end{array}$ & $\begin{array}{l}\text { The appropriate increase in } \\
\text { leadership style practice by shared } \\
\text { instructional leadership may not be }\end{array}$ \\
\hline
\end{tabular}




\section{International Journal of Current Science Research and Review}

ISSN: 2581-8341

Volume 03 Issue 12 December 2020

DOI: 10.47191/ijcsrr/V3-i12-10, Impact Factor: 6.595

IJCSRR@ 2020

www.ijcsrr.org

Practice Shared instructional

defined by categorized needs.

Leadership

(Urick, 2016)

$\begin{array}{llll}\text { Stefan } & \text { No time to manage? The Germany } & \text { Quantitative, } & \text { Sample of } \\ \text { Brauckma } & \text { trade-off between relevant } & \text { regression } & 153 \text { school } \\ \text { nn, } & \text { tasks and actual priorities of } & \text { model, } & \text { leaders from } \\ \text { Alexandra } & \text { school leaders in Germany } & \text { empirical six federal } \\ \text { Schwarz } & & \text { analysis states } \\ (2015) & \text { using data } \\ & \text { collected in } \\ & \text { the German } \\ & \text { SHaRP } \\ & \text { study }\end{array}$

Management and organizational and personnel development are stated to be most important for leadership activities. This priority is at least not reflected in the distribution of workloads observed over areas of activity. Rather, a lot of time - as long as it is not absorbed by lessons - is spent on administrative tasks (Brauckmann, Thiel, Kuper, Tarkian, \& Schwarz, 2015).

$\begin{array}{llr}\text { Diya Dou, } & \text { The relationships between } \\ \text { Geert } & \text { school autonomy gaps, } \\ \text { Devos, } & \text { principal } \\ \text { and } & \text { teachers' job satisfaction, } \\ \text { Martin } & \text { and } \\ \text { Valcke } & \text { commitment }\end{array}$

Quantitative 48 Principals Significant instructional and transformational leadership on teacher job satisfaction, and organizational commitment, which is mediated by the indirect impact of school climate and teacher selfefficacy (Dou, Devos, \& Valcke, 2017)

$\begin{array}{ll}\begin{array}{l}\text { Emma } \\ \text { claire }\end{array} & \begin{array}{l}\text { Should inclusive education } \\ \text { be made compulsory in }\end{array} \\ \text { Pearson } & \text { schools ?: a study of self- } \\ \text { Jennifer } & \text { efficacy and attitudes } \\ \text { Tan } & \text { regarding inclusive } \\ (2015) & \text { education among a diverse } \\ & \text { group of SNA (special needs } \\ & \text { assistance) teachers }\end{array}$

$\begin{array}{lll}\text { Brunei } & \text { Data } & 76 \quad \text { people } \\ \text { Darussalam } & \begin{array}{l}\text { collection } \\ \text { methods }\end{array} & \begin{array}{l}\text { attended } \\ \text { workshop and } \\ \text { completing a } \\ \text { shortened } \\ \text { version of the } \\ \text { self-efficacy } \\ \end{array} \\ & & \text { questionnaire }\end{array}$

\begin{tabular}{llll}
\hline Joanna & Inclusive education in Australia & Qualitative & Thi \\
Anderson & Australia: rhetoric, reality & (Extensive & nati \\
and & and the road ahead & review of & Edu \\
Christoph & & literature) & dev
\end{tabular}

er Boyle

(2015)

The real relationship between selfefficacy and negative responses to items. Based on data from this sample of SENA teachers, it appears that high self-efficacy is likely not, as is widely assumed, to result in a positive outlook on inclusive education. (Pearson \& Tan, 2015) This paper discusses the need for a national approach to Inclusive Education the sustainable development of effective schools for all students across Australia. Much has been learned since Australia adopted the philosophy of Inclusive Education nearly two decades ago. Research shows that current practice has not fulfilled the original intent of the Inclusive Education movement (Anderson \& Boyle, 2015)

\begin{tabular}{|c|c|c|c|c|c|}
\hline $\begin{array}{l}\text { Sailajah } \\
\text { Sukumara } \\
\text { na, Judith }\end{array}$ & $\begin{array}{l}\text { Inclusion in Malaysian } \\
\text { integrated preschools }\end{array}$ & Malaysia & Quantitative & 113 preschool & $\begin{array}{l}\text { This study shows that despite the } \\
\text { government's mandate and } \\
\text { comprehensive guidelines on }\end{array}$ \\
\hline
\end{tabular}




\section{International Journal of Current Science Research and Review}

ISSN: 2581-8341

Volume 03 Issue 12 December 2020

DOI: 10.47191/ijcsrr/V3-i12-10, Impact Factor: 6.595

IJCSRR@ 2020

www.ijcsrr.org

Loveridge

$\mathrm{b} *$ and

Vanessa

A. Greenb

(2015) implementing inclusion there is ongoing debate on various issues regarding inclusion and whether children with special needs should be fully educated in ordinary classrooms or if separated special class-rooms are still relevant. Therefore, government support and legislation alone cannot guarantee antee inclusion; Conversely, successful inclusion must be supported by positive attitudes, significant processes and research evidence on how inclusive education can effectively meet the individual needs of children with special needs (Sukumaran, Loveridge, \& Green, 2015)

$\begin{array}{llll}\text { Lucy Inclusive education: teacher } & \text { Malaysia } & \text { Quantitative } & 300 \\ \text { Baileya, } & \text { perspectives from Malaysia } & \text { Malaysian } \\ \text { Alefiya } & & \text { primary } \\ \text { Nomanbh } & \text { school } \\ \text { oya \& } & & \text { teachers were } \\ \text { Tida } & & \text { involved }\end{array}$

Tubpuna

(2015)

Demonstrates that Malaysian
teachers continue to have generally positive attitudes toward the principle of inclusion. However, they also continue to believe that those children with special educational needs benefit academically from spending time in designated classrooms. Moreover and this is an important finding despite the intervening period and commitment of the Malaysian government to inclusion, the view appears to be more assertive because Malaysian teachers do not have adequate training and skills to support children with special educational needs (Bailey, Nomanbhoy, \& Tubpun, 2015)

\begin{tabular}{|c|c|c|c|c|c|}
\hline $\begin{array}{l}\text { Olufemi } \\
\text { Aremu } \\
\text { Fakolad, } \\
\text { Samuel } \\
\text { Olufemi } \\
\text { Adeniyi, } \\
\text { Adeyinka } \\
\text { Tella } \\
(2017)\end{array}$ & $\begin{array}{l}\text { Attitude of teachers towards } \\
\text { the inclusion of special } \\
\text { needs children in general } \\
\text { education classroom: the } \\
\text { case of teachers in some } \\
\text { selected schools in Nigeria }\end{array}$ & Norway & $\begin{array}{l}\text { Descriptiv; } \\
\text { survey } \\
\text { research } \\
\text { design }\end{array}$ & $\begin{array}{l}60 \text { teachers as } \\
\text { participants } \\
\text { from selected } \\
\text { secondary } \\
\text { schools in } \\
\text { Oyo State, } \\
\text { Nigeria }\end{array}$ & $\begin{array}{l}\text { Female teachers have a more } \\
\text { positive attitude towards the } \\
\text { inclusion of special needs students } \\
\text { than boys, there is a significant } \\
\text { difference between married and } \\
\text { single teachers in their attitudes } \\
\text { towards students with special } \\
\text { needs. And that teachers who are } \\
\text { professionally qualified tend to } \\
\text { have attitudes that are more }\end{array}$ \\
\hline
\end{tabular}




\section{International Journal of Current Science Research and Review}

ISSN: 2581-8341

Volume 03 Issue 12 December 2020

DOI: 10.47191/ijcsrr/V3-i12-10, Impact Factor: 6.595

IJCSRR@ 2020

WWw.ijcsrr.org

supportive of the inclusion of students with special needs than teachers with non-professional qualifications. It used to recommend that teachers should attend seminars and conferences to increase their ability to know how to practice and accept inclusion for a better tomorrow for children with special needs in Nigeria (Fakolade, Adeniyi, \& Tella, 2017)

\begin{tabular}{|c|c|c|c|c|c|}
\hline $\begin{array}{l}\text { Petra } \\
\text { Engelbrec } \\
\text { ht, Mirna } \\
\text { Nel, } \\
\text { Suegnet } \\
\text { Smit \& } \\
\text { Marichell } \\
\text { e van } \\
\text { Deventer } \\
\text { (2016) }\end{array}$ & $\begin{array}{l}\text { The idealism of education } \\
\text { policies and the realities in } \\
\text { schools: the implementation } \\
\text { of inclusive education in } \\
\text { South Africa }\end{array}$ & $\begin{array}{l}\text { South } \\
\text { Africa }\end{array}$ & $\begin{array}{l}\text { Constant } \\
\text { comparative } \\
\text { analysis }\end{array}$ & $\begin{array}{l}\text { Constructivist } \\
\text { research } \\
\text { paradigm in } 2 \\
\text { schools }\end{array}$ & $\begin{array}{l}\text { The constructivist research } \\
\text { paradigm in } 2 \text { full-service schools } \\
\text { in rural cities revealed interesting } \\
\text { results that illustrate the complexity } \\
\text { of implementing inclusive } \\
\text { education and the challenges and } \\
\text { opportunities in bridging the gap } \\
\text { between policy idealism and reality } \\
\text { in schools (Engelbrecht, Nel, Smit, } \\
\text { \& Van Deventer, 2016) }\end{array}$ \\
\hline $\begin{array}{l}\text { Ting } \\
\text { Wang } \\
(2016)\end{array}$ & $\begin{array}{l}\text { School leadership and } \\
\text { professional learning } \\
\text { community: a case study of } \\
\text { two senior high schools in } \\
\text { Northeast China }\end{array}$ & China & $\begin{array}{l}\text { Qualitative } \\
\text { and } \\
\text { interpretive }\end{array}$ & $\begin{array}{l}\text { The } 20 \\
\text { participants } \\
\text { consisted of } \\
\text { two school } \\
\text { principals, four } \\
\text { deputy } \\
\text { principals, } \\
\text { and 14 teachers } \\
\text { at various } \\
\text { levels with } \\
\text { teaching } \\
\text { experience } \\
\text { ranging from } \\
\text { two to } 35 \\
\text { years. }\end{array}$ & $\begin{array}{l}\text { School leaders demonstrate their } \\
\text { strength, instructional leadership, } \\
\text { and visionary supervision for } \\
\text { sustainable school improvement. } \\
\text { They play an important role in } \\
\text { developing and communicating } \\
\text { various visions, forming a culture } \\
\text { of belief, supporting and } \\
\text { monitoring collegial learning } \\
\text { (Wang, 2016) }\end{array}$ \\
\hline
\end{tabular}

\section{RESULTS AND DISCUSSIONS}

From this study literature review through several articles that the author has read, analysis of research on principal leadership in the implementation of inclusive education in various countries in the world, there are various ways of collecting data related to principal leadership and the implementation of inclusive education in the world. The most commonly used are interviews and observations. Research on principal leadership and the implementation of inclusive education in the world has been carried out in various countries. Table 1 shows that research has been carried out in schools and universities from various countries (America, Canada, Texas, South Africa, Finland, Malaysia, China, Turkey, Singapore, Australia, Norway, Germany, Brunei Darussalam, Philippines, Vietnam, and other countries; Asia Indo-Pacific, namely Bangladesh, Sri Lanka, Bhutan, Kiribati, Pacific Islands, and Macau). The results of the research mostly indicate that the true meaning of 'inclusion' is always related to the study participants' own understanding and significant changes in the student population with the special needs of students who currently come from various basic backgrounds with a wide spectrum of new types of special needs (Jahnukainen, 2015) 


\section{International Journal of Current Science Research and Review}

ISSN: 2581-8341

Volume 03 Issue 12 December 2020

DOI: 10.47191/ijcsrr/V3-i12-10, Impact Factor: 6.595

IJCSRR@ 2020

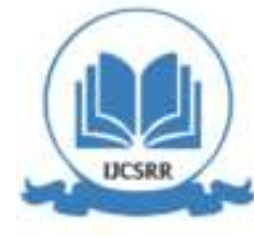

www.ijcsrr.org

Understanding and practicing of inclusive education, and the main challenges in developing inclusive education, It only deals with issues of broader relevance revealed in the research literature. The content has included elements related to the definition of inclusive education in terms of horizontal and vertical dimensions, inclusive education practices, benefits of inclusive education, and teacher competence for inclusive education (Haug, 2017). Describes how various relationships and mitigation sharing between individuals and communities can support work in individual countries in promoting and sustaining inclusive education (Carrington et al., 2019). Research shows that students with special learning needs are frequently harassed in classrooms and in public schools, or teased and bullied, which negatively impacts their self-image; reported, $70 \%$ of children from different cultures experience some form of racism in school, especially when English is not the first language (Mansouri \& Jenkins, 2010).

For schools to be truly inclusive, inclusion must be a way of thinking, a philosophy of how educators remove barriers to learning and value all members of the school community (J. L. McLeskey, Rosenberg, \& Westling, 2017). Inculcating the practice of inclusive education requires a way of leading a different school culture that prioritizes building and maintaining positive relationships is the basis for the establishment of inclusive schools (Zollers, Ramanathan, \& Yu, 1999).

With this in mind, leadership styles and practices facilitate the creation of inclusive school culture. Both help creates basic norms and assumptions that are taken for granted by all those in the school community (Schein, 2010).

Operationally, at the school level as a whole, this involves adjusting policies and practices, funding support, using support structures, and access to equitable learning opportunities. The level of inclusion of support in the classroom involves understanding individual learning needs and developing an appropriate individual learning plan. This level of support usually involves different curricula, sometimes providing alternative curricula, leveraging appropriate pedagogy for student engagement such as universal design, and providing appropriate access to alternative resources (Sharma, Forlin, \& Loreman, 2008).

This lesson, therefore, concentrates on the role of appointed leaders in building a culture of inclusion, rather than exploring all aspects of leadership practice that emerge from the data. Social justice leadership can be seen to be based on the formation of meaningful relationships that encourage socially just teaching practices and policies, promote inclusion, and seek equity for all students (Shields, 2004). Principals take on seven key roles as they work as special education leaders: visionary, partner, trainer, conflict resolver, advocate, interpreter, and organizer (Cobb, 2015). It is also recognized that the position of school leaders must have a philosophy and mind-set that seeks to build a distributed leadership capacity throughout their school, empowering others to lead (Morgan, 2008).

School leaders demonstrate their strength, instructional leadership, and visionary supervision for sustainable school improvement. They play an important role in developing and communicating various visions, forming a culture of belief, supporting, and monitoring collegial learning (Wang, 2016). Principals demonstrate the virtue of wisdom and knowledge in creating long-term provisions for their schools and building schools for future generation (Eisenschmidt et al., 2019). School leadership for inclusion involves making difficult decisions. It is a complex and multifaceted course of action that requires conscious targeted effort, advocacy, and a certain way of leading. Inclusive practices need to be strengthened with hope, support, and recognition that for all stakeholders, towards a common vision (Carter \& Abawi, 2018).

The leadership skills, action, and persistence involved in creating more socially just schools are important and often paralyze school principals because social justice leadership can create many dilemmas and challenges (DeMatthews \& Mawhinney, 2014). Measuring the success of, or not, Inclusive Education is complex and challenging (Forlin, Chambers, Loreman, Deppler, \& Sharma, 2013). To see the success of Inclusive Education through the lens of its results: student participation, student achievement, and postschool outcomes (Loreman, 2014).

\section{CONCLUSION}

From the journal that the authors have successfully reviewed about principals' role and the implementation of inclusive education carried out in various countries in the world, the authors conclude that (1) principals apply different leadership styles and (2) principals apply different leadership styles and strategies. (3) The factors that influence different styles and strategies are diverse resources, government policies, and local values.

\section{LIMITATION AND STUDY FORWARD}

This review study has limitations: First, the articles reviewed were in English only so other studies were not reviewed due to limitations. Second, the number and scope of articles reviewed are limited. In Indonesia, the articles identified covered principal 


\section{International Journal of Current Science Research and Review}

ISSN: 2581-8341

Volume 03 Issue 12 December 2020

DOI: 10.47191/ijcsrr/V3-i12-10, Impact Factor: 6.595

IJCSRR@ 2020

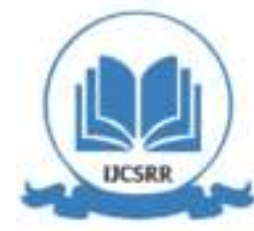

www.ijcsrr.org

leadership and implementation of inclusive education. The term full inclusion was first applied in the field of special education to describe how all students with disabilities should be included in the general classroom throughout the school day (J. McLeskey \& Waldron, 2011). School leadership for inclusion involves difficult decision making. It is a complex and multifaceted act that requires deliberate effort, advocacy and a certain way of leading. Inclusive practices need to be strengthened with hope, support and recognition which, for all stakeholders, lead to a common vision (Carter \& Abawi, 2018). There are hopes that schools will engage students through inclusive practices, but the term 'inclusion' has created ideological divisions, especially with regard to special education, with some theorists advocating for full inclusion and others for a more needs-based approach (Florian, 2015).

The authors suggest that to remove barriers to education and deliver high-quality outcomes, schools need inclusive practices that embrace all students as valued affiliates of the school community, with inclusion as a vision, operationalized at the school community, the whole school, and the individual level. Inclusion refers to an individual's right to participate actively and achieve equality through involvement in all aspects of everyday life (Hyde, Carpenter, \& Conway, 2013).

\section{ACKNOWLEDGEMENT}

The greatest appreciation is given to people who have helped, supported and provided motivation and guidance in completing articles. Thank you to Hasan Hariri, Sowiyah, and Riswanti Rini, finally, and thank you to the University of Lampung.

\section{REFERENCES}

1. Anderson, J., \& Boyle, C. (2015). Inclusive education in Australia: rhetoric, reality and the road ahead. Support for Learning, 30(1), 4-22. doi: https://doi.org/10.1111/1467-9604.12074

2. Armstrong, J. (2006). How principals lead to promote inclusive practices: A descriptive study.

3. Bailey, L., Nomanbhoy, A., \& Tubpun, T. (2015). Inclusive education: Teacher perspectives from Malaysia. International Journal of Inclusive Education, 19(5), 547-559. doi: https://doi.org/10.1080/13603116.2014.957739

4. Bennis, W., Nanus, B., \& Purba, V. (, 1990). Kepimpinan: strategi dalam mengemban tanggung jawab: Penerbit Erlangga.

5. Bennis, W., \& Townsend, R. (1998). Reinventing Leadership (Terjemahan oleh Clara Suwendo: Menciptakan Kembali Kepemimpinan). Batam Centre: Interaksara.

6. Brauckmann, S., Thiel, F., Kuper, H., Tarkian, J., \& Schwarz, A. (2015). No time to manage? The trade-off between relevant tasks and actual priorities of school leaders in Germany. International Journal of Educational Management.

7. Brooks, M. C., \& Brooks, J. S. (2019). Culturally (ir) relevant school leadership: Ethno-religious conflict and school administration in the Philippines. International Journal of Leadership in Education, 22(1), 6-29.

8. Carrington, S., Tangen, D., \& Beutel, D. (2019). Inclusive education in the Asia Indo-Pacific region: Taylor \& Francis.

9. Carter, S., \& Abawi, L.-A. (2018). Leadership, inclusion, and quality education for all. Australasian Journal of Special and Inclusive Education, 42(1), 49-64.

10. Cobb, C. (2015). Principals play many parts: a review of the research on school principals as special education leaders 2001-2011. International Journal of Inclusive Education, 19(3), 213-234.

doi: https://doi.org/10.1080/13603116.2014.916354

11. DeMatthews, D. (2015). Making sense of social justice leadership: A case study of a principal's experiences to create a more inclusive school. Leadership and Policy in schools, 14(2), 139-166. doi: https://doi.org/10.1080/15700763.2014.997939

12. DeMatthews, D., \& Mawhinney, H. (2014). Social justice leadership and inclusion: Exploring challenges in an urban district struggling to address inequities. Educational Administration Quarterly, 50(5), 844-881. doi: https://doi.org/10.1177/0013161X13514440

13. Dou, D., Devos, G., \& Valcke, M. (2017). The relationships between school autonomy gap, principal leadership, teachers' job satisfaction and organizational commitment. Educational Management Administration \& Leadership, 45(6), 959-977. doi: https://doi.org/10.1177/1741143216653975

14. Eisenschmidt, E., Kuusisto, E., Poom-Valickis, K., \& Tirri, K. (2019). Virtues that create purpose for ethical leadership: Exemplary principals from Estonia and Finland. Journal of Beliefs \& Values, 40(4), 433-446. doi: https://doi.org/10.1080/13617672.2019.1618152. 
ISSN: 2581-8341

Volume 03 Issue 12 December 2020

DOI: 10.47191/ijcsrr/V3-i12-10, Impact Factor: 6.595

IJCSRR@ 2020

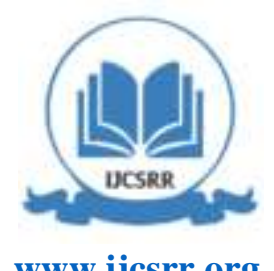

15. Engelbrecht, P., Nel, M., Smit, S., \& Van Deventer, M. (2016). The idealism of education policies and the realities in schools: The implementation of inclusive education in South Africa. International Journal of Inclusive Education, 20(5), 520-535. doi: https://doi.org/10.1080/13603116.2015.1095250

16. Fakolade, O. A., Adeniyi, S. O., \& Tella, A. (2017). Attitude of teachers towards the inclusion of special needs children in general education classroom: the case of teachers in some selected schools in Nigeria. International Electronic Journal of elementary education, 1(3), 155-169.

17. Florian, L. (2015). Inclusive Pedagogy: A transformative approach to individual differences but can it help reduce educational inequalities. Scottish Educational Review, 47(1), 5-14.

18. Forlin, C. I., Chambers, D. J., Loreman, T., Deppler, J., \& Sharma, U. (2013). Inclusive education for students with disability: A review of the best evidence in relation to theory and practice.

19. Gibson et al (, 1997). Perilaku struktur, proses, jilid2. Jakarta: Binarupa Aksara.

20. Hairon, S., \& Goh, J. (2017). Teacher leadership in singapore and its potential. Asia Leadership Roundtable. Hong Kong (China): Asia Pacific Centre for Leadership and Change, 1-17.

21. Haug, P. (2017). Understanding inclusive education: ideals and reality. Scandinavian Journal of Disability Research, 19(3), 206-217. doi: https://doi.org/10.1080/15017419.2016.1224778

22. Hyde, M., Carpenter, L., \& Conway, R. N. (2013). Diversity, inclusion and engagement: Oxford University Press Melbourne, VIC, Australia.

23. Indonesia, P. R. (2003). Undang-undang Republik Indonesia nomor 20 tahun 2003 tentang sistem pendidikan nasional. Jakarta: Pemerintah Republik Indonesia.

24. Iswari, M. (2007). Pendidikan Kecakapan Hidup Bagi Anak Berkebutuhan Khusus.

25. Jahnukainen, M. (2015). Inclusion, integration, or what? A comparative study of the school principals' perceptions of inclusive and special education in Finland and in Alberta, Canada. Disability \& Society, 30(1), 59-72. doi: https://doi.org/10.1080/09687599.2014.982788

26. Jones, M., Adams, D., Hwee Joo, M. T., Muniandy, V., Perera, C. J., \& Harris, A. (2015). Contemporary challenges and changes: principals' leadership practices in Malaysia. Asia Pacific Journal of Education, 35(3), 353-365. doi: https://doi.org/10.1080/02188791.2015.1056591https://doi.org/10.1080/02188791.2015.1056591

27. Karatas, İ. H. (2016). Professional standards for school principals in Turkey. Journal of Education and Training Studies, 4(5), 51-63. doi: https://doi.org/10.11114/jets.v4i5.1310

28. Kouzes, J. M., \& Posner, B. Z. (2006). The leadership challenge (Vol. 3): John Wiley \& Sons.

29. Kugelmass, J. W. (2003). Inclusive leadership: Leadership for inclusion.

30. Kunc, N. (1992). The need to belong: Rediscovering Maslow's hierarchy of needs.

31. Leithwood, K., Harris, A., \& Hopkins, D. (, 2020). Seven strong claims about successful school leadership revisited. School leadership \& management, 40(1), 5-22. doi: https://doi.org/10.1080/13632434.2019.1596077

32. Li, L., Hallinger, P., \& Ko, J. (2016). Principal leadership and school capacity effects on teacher learning in Hong Kong. International Journal of Educational Management. doi: https://www.emerald.com/insight/content/doi/10.1108/IJEM-032014-0035/full/html

33. Loreman, T. (2014). Measuring inclusive education outcomes in Alberta, Canada. International Journal of Inclusive Education, 18(5), 459-483. doi: https://doi.org/10.1080/13603116.2013.788223

34. Mansouri, F., \& Jenkins, L. (2010). Schools as Sites of Race Relations and Intercultural Tension. Australian journal of teacher education, 35(7), 93-108.

35. Marzano, R. J., Waters, T., \& McNulty, B. A. (2001). School leadership that works: From research to results: ASCD.

36. McLeskey, J., \& Waldron, N. L. (2011). Educational programs for elementary students with learning disabilities: Can they be both effective and inclusive? Learning Disabilities Research \& Practice, 26(1), 48-57. doi: https://doi.org/10.1111/j.15405826.2010.00324.x

37. McLeskey, J. L., Rosenberg, M. S., \& Westling, D. L. (2017). Inclusion: Effective practices for all students: Pearson.

38. Morgan, A. R. (2008). The principal in a process of school revitalisation: A metastrategic role. University of Southern Queensland. Retrieved from http://eprints.usq.edu.au/id/eprint/4077 


\section{International Journal of Current Science Research and Review}

ISSN: 2581-8341

Volume 03 Issue 12 December 2020

DOI: 10.47191/ijesrr/V3-i12-10, Impact Factor: 6.595

IJCSRR @ 2020

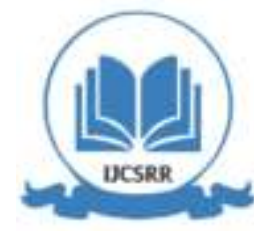

www.ijcsrr.org

39. Pearson, E. C., \& Tan, J. (2015). Should Inclusive Education Be Made Compulsory in Schools?: A Study of Self-Efficacy and Attitudes Regarding Inclusive Education among a Diverse Group of SENA (Special Needs Assistance) Teachers. International Journal of Special Education, 30(1), 111-119.

40. Quin, J., Deris, A., Bischoff, G., \& Johnson, J. T. (, 2015). Comparison of Transformational Leadership Practices: Implications for School Districts and Principal Preparation Programs. Journal of Leadership Education, 14(3). doi: DOI: 1012806/V14/I3/R5

41. Robbins, S. P. (, 2002). Perilaku organisasi: Konsep, kontroversi, aplikasi. Jakarta: Penerbit PT Prenhallindo.

42. Rosenbloom, D. (2014). Public administration: Understanding management, politics, and law in the public sector: McGrawHill Higher Education.

43. Ryan, J. (2006). Inclusive leadership and social justice for schools. Leadership and Policy in schools, 5(1), 16 - 18. doi: https://doi.org/10.1080/15700760500483995

44. Ryan, J. (, 2006a). Inclusive leadership and social justice for schools. Leadership and Policy in schools, 5(1), 16 -18 Schein, E. H. (2010). Organizational culture and leadership (Vol. 2): John Wiley \& Sons.

45. Sharma, U., Forlin, C., \& Loreman, T. (2008). Impact of training on pre-service teachers' attitudes and concerns about inclusive education and sentiments about persons with disabilities. Disability \& Society, 23(7), 773-785.

46. Shields, C. M. (2004). Dialogic leadership for social justice: Overcoming pathologies of silence. Educational Administration Quarterly, 40(1), 109-132. doi: doi:10.1177 / 0013161X03258963

47. Smit, B., \& Scherman, V. (2016). A case for relational leadership and an ethics of care for counteracting bullying at schools. South African Journal of Education, 36(4), 1-9. doi: DOI: 10.15700/saje.v36n4a1312

48. Smith, J. D. (2009). Inclusion, School for All Student (Inklusi Sekolah Ramah untuk Semua). Editor: M. Sugiarmin, MIF Baihaqi, Nuansa, Bandung.

49. Sukumaran, S., Loveridge, J., \& Green, V. A. (2015). Inclusion in Malaysian integrated preschools. International Journal of Inclusive Education, 19(8), 821-844. doi: https://doi.org/10.1080/13603116.2014.981229

50. Tingle, E., Corrales, A., \& Peters, M. L. (2019). Leadership development programs: Investing in school principals. Educational Studies, 45(1), 1-16. doi: https://doi.org/10.1080/03055698.2017.1382332

51. Truong, T. D., Hallinger, P., \& Sanga, K. (2017). Confucian values and school leadership in Vietnam: Exploring the influence of culture on principal decision making. Educational Management Administration \& Leadership, 45(1), 77-100. doi: https://doi.org/10.1177/1741143215607877

52. UNESCO. (1990). World declaration on education for all: UNESCO Paris.

53. UNESCO. (1994a). The Salamanca statement and framework for action on special needs education: UNESCO Paris.

54. Unesco. (1994b). The Salamanca Statement and Framework for action on special needs education: Adopted by the World Conference on Special Needs Education; Access and Quality. Salamanca, Spain, 7-10 June 1994: Unesco.

55. UNESCO. (2003). Inclusive education: A Challange and a vision 6(1), 122.

56. Urick, A. (2016). Examining US principal perception of multiple leadership styles used to practice shared instructional leadership. Journal of Educational Administration. doi: https://doi.org/10.1108/JEA-07-2014-0088

57. Wang, T. (2016). School leadership and professional learning community: Case study of two senior high schools in Northeast China. Asia Pacific Journal of Education, 36(2), 202-216. doi: https://doi.org/10.1080/02188791.2016.1148849

58. Zollers, N. J., Ramanathan, A. K., \& Yu, M. (1999). The relationship between school culture and inclusion: How an inclusive culture supports inclusive education. International Journal of Qualitative Studies in Education, 12(2), 157-174. doi: https://doi.org/10.1080/095183999236231

Cite this Article: Lilis Afrianti, Ridwan Ridwan, Hasan Hariri, Riswanti Rini, Sowiyah Sowiyah (2020). Principals Role in Inclusive Education: A Literature Review. International Journal of Current Science Research and Review, 3(12), 271-284 